\title{
Trends in the Prevalence of Live Macrosomic Newborns According to Gestational Age Strata, in Brazil, 2001-2010, and 2012-2014
}

\section{Tendências na prevalência de recém-nascidos vivos macrossômicos, estratificadas por idade gestacional, Brasil, 2001-2010 e 2012-2014}

\author{
Maria Isabel do Nascimento ${ }^{1}$ Daniele Francine Pereira ${ }^{2}$ Calliana Lopata ${ }^{2}$ \\ Carina Ladeia Flores Oliveira ${ }^{2}$ Ariane Arruda de Moura ${ }^{2}$ Maria Júlia da Silva Mattos ${ }^{2}$ \\ Lucas Saraiva da Silva ${ }^{2}$
}

${ }^{1}$ Department of Epidemiology and Biostatistics, Instituto de Saúde Coletiva, Universidade Federal Fluminense, Niterói, RJ, Brasil

2 Medical Students, Faculdade de Medicina, Universidade Federal

Address for correspondence Maria Isabel do Nascimento, PhD, Hospital Universitário Antonio Pedro, Secretaria da Coordenação de Medicina, Rua Marquês do Paraná, 303, Centro, Niterói (RJ), Brasil Fluminense, Niterói, RJ, Brasil (e-mail: ysamaria@uol.com.br).

Rev Bras Ginecol Obstet 2017;39:376-383.

\begin{abstract}
Purpose To describe the trends in the prevalence of macrosomia (birth weight $\geq 4,000 \mathrm{~g}$ ) according to gestational age in Brazil in the periods of 2001-2010 and 2012-2014.

Methods Ecological study with data from the Brazilian Live Birth Information System (SINASC, in the Portuguese acronym) regarding singleton live newborns born from 22 gestational weeks. The trends in Brazil as a whole and in each of its five regions were analyzed according to preterm (22-36 gestational weeks) and term (37-42 gestational weeks) strata. Annual Percent Changes (APCs) based on the Prais-Winsten method and their respective $95 \%$ confidence intervals (Cls) were used to verify statistically significant changes in 2001-2010.

Results In Brazil, the prevalence of macrosomic births was of 5.3\% (2001-2010) and $5.1 \%$ (2012-2014). The rates were systematically higher in the North and Northeast Regions both in the preterm and in term strata. In the preterm stratum, the North

Keywords

- macrosomia

- prevalence

- trends

- epidemiology

- maternal health

- child health Region presented the highest variation in the prevalence of macrosomia $(+137.5 \%)$ when comparing $2001(0.8 \%)$ to 2010 (1.9\%). In the term stratum, downward trends were observed in Brazil as a whole and in every region. The trends for 2012-2014 were more heterogeneous, with the prevalence systematically higher than that observed for 2001-2010. The APC in the preterm stratum (2001-2010) showed a statistically significant trend change in the North (APC: $15.4 \%$; 95\%Cl: 0.6-32.3) and South (APC: $13.5 \%$; $95 \% \mathrm{Cl}: 4.8-22.9)$ regions. In the term stratum, the change occurred only in the North region (APC:-1.5\%; 95\%Cl: -2.5--0.5).
\end{abstract}

received

January 8, 2017

accepted

May 24, 2017
DOI https://doi.org/

10.1055/s-0037-1604266. ISSN 0100-7203.
Copyright (e 2017 by Thieme Revinter

Publicações Ltda, Rio de Janeiro, Brazil
License terms

(c) $(1) \$$ 


\section{Resumo}

\section{Palavras-chave \\ - macrossomia fetal \\ - prevalência \\ - tendências \\ - epidemiologia \\ - saúde materna \\ - saúde da criança}

Conclusion The prevalence of macrosomic births in Brazil was higher than $5.0 \%$. Macrosomia has potentially negative health implications for both children and adults, and deserves close attention in the public health agenda in Brazil, as well as further support for investigation and intervention.

Objetivo Descrever tendências nas prevalências de macrossomia (peso ao nascer $\geq 4.000 \mathrm{~g}$ ) segundo idade gestacional no Brasil em 2001-2010 e em 2012-2014.

Métodos Estudo ecológico com dados do Sistema de Informação sobre Nascidos Vivos (SINASC), incluindo bebês nascidos vivos a partir de 22 semanas, de gestações únicas. As tendências no Brasil como um todo e nas suas cinco regiões foram analisadas nos estratos pré-termo (22-36 semanas de gestação) e termo (37-42 semanas de gestação). Mudanças percentuais anuais (APCs) baseadas nos modelos de regressão propostos por Prais-Winsten e intervalos de confiança (ICs) de $95 \%$ foram calculados para verificar diferenças estatisticamente significantes no período 2001-2010.

Resultados No Brasil, a prevalência de macrossomia foi de 5,3\% (2001-2010) e 5,1\% (2012-2014). As frequências foram sistematicamente maiores nas regiões Norte e Nordeste, tanto no pré-termo quanto no termo. No pré-termo, a região Norte apresentou a variação mais importante na prevalência de macrossomia $(+137,5 \%)$ quando comparados o ano de $2001(0,8 \%)$ e o de 2010 (1,9\%). No termo, tendências declinantes foram observadas no Brasil e em todas as suas regiões. As tendências em 2012-2014 foram mais heterogêneas, com frequências maiores do que aquelas observadas em 2001-2010. As APCs no estrato pré-termo (2001-2010) mostraram que as mudanças foram estatisticamente significantes no Norte (APC: 15,4\%; IC95\%: 0,6-32,3) e no Sul (APC: 13,5\%; IC95\%: 4,8-22,9). No termo, a mudança ocorreu apenas no Norte (APC: -1,5\%; IC95\%: -2,5--0,5).

Conclusão A prevalência de macrossomia no Brasil foi maior do que 5,0\%. A macrossomia tem implicações potencialmente negativas para a saúde da criança e do adulto, e merece mais atenção das políticas de saúde pública no Brasil, bem como mais apoio para investigação e intervenção.

\section{Introduction}

The term fetal macrosomia implies fetal growth beyond a specific weight, regardless of the fetal gestational age. ${ }^{1}$ However, there is little consensus on the cut-off weight that properly allows to classify newbornss as macrosomic. ${ }^{2}$ Definitions based on percentiles are dependent on gestational age ${ }^{3}$ and regional features. ${ }^{4}$ These parameters increase the complexity to estimate the fetus' measures, and this limits their use in the obstetric practice. Simpler classifications based only on the cut-off weight are commonly used, and macrosomic newborns are considered those who were born with a birth weight $\geq 4,000 \mathrm{~g}^{5}$ or $\geq 4,500 \mathrm{~g}$. ${ }^{3,6}$

Even though low birth weight is an issue of major interest in the specialized scientific literature focusing on unfavorable perinatal outcomes, the effects of macrosomia are also adverse, with potentially serious consequences for the mothers and newborns. ${ }^{3}$ Maternal problems include high frequency of cesarean sections, perineum lacerations, postpartum hemorrhage, prolonged hospitalization, and puerperal infections. The newborns are at risk of shoulder dystocia, fracture, intrauterine hypoxemia, intensive care unit admission and death., ${ }^{7,8}$
Besides the potential for immediate injuries to both the mothers and the newborns, macrosomia is suspected to be related to long-term harmful health effects, such as increased risk of developing obesity during childhood ${ }^{9}$ and adulthood, ${ }^{10}$ as well as cancer, ${ }^{11}$ diabetes, ${ }^{12}$ and other chronic diseases.

The conditions associated to macrosomia include pregestational and gestational diabetes mellitus, maternal obesity, and gestational weight gain, ${ }^{2}$ which may be reasonably controlled via adequate prenatal care. Considering prenatal care as universally offered in Brazil, and the scarce scientific literature investigating macrosomia at the population level, this study aimed to describe trends in the prevalence of live newborns weighing $\geq 4,000 \mathrm{~g}$ according to gestational age strata, in Brazil and in its five regions, in the periods of 2001-2010 and 2012-2014.

\section{Methods}

This is an ecological study based on nationwide information provided by the Department of Informatics of the Brazilian Unified Healthcare System (DATASUS, in the Portuguese 
acronym), the main national vital statistics subsystems coordinator in Brazil. The Brazilian Live Births Information System (SINASC, in the Portuguese acronym) is the subsystem that stores epidemiologic information on live births in Brazil, and it is the source of the variables (namely year of birth, number of live newborns, gestational age, and birth weight) used in the present study. All live newborns from singleton pregnancies from 22 gestational weeks from 2001 to 2010 and from 2012 to 2014 were included in the study. The data for 2011 were not used because the gestational age field in the birth certificate form was modified in that year, and its inclusion could cause the erroneous classification of some babies in regard to gestational age. The definition of macrosomia was based on the cut-off birth weight $\geq 4,000 \mathrm{~g}$.

Prevalence of macrosomic births in Brazil as a whole and in its five regions (North, Northeast, Midwest, Southeast and South) was calculated for each year, for all live newborns from 22 gestational weeks, for preterm newborns (from 22 to 36 gestational weeks), and for term newborns (from 37 to 42 gestational weeks). Considering the improvement in coverage and data quality provided by the SINASC in more recent years, a correction factor created by Szwarcwald et al ${ }^{13}$ was used to reduce the effect of underreported births only during the 2001-2010 period, so as to more accurately represent the real number of live births in Brazil.

As differences between the SINASC data and the primary data studied by Silveira et al ${ }^{14}$ were more marked involving newborns weighing up to $3,000 \mathrm{~g}$, with lower or no significant difference above this weight group, no factor was used to correct the birth weight $\geq 4,000 \mathrm{~g}$ in relation to gestational age.

\section{Secular Trends Analysis}

First, a trend assessment (increasing, decreasing, or stationary) was visually obtained through the inspection of specific graphs for Brazil as a whole. The dependent variable (prevalence of live newborns weighing $\geq 4,000 \mathrm{~g}$ ) was placed on the $y$-axis and correlated with the independent variable (year of birth), which was placed on the x-axis. The analyses were repeated for each of the five Brazilian regions.

\section{Trend Variation in the 2001-2010 Period}

Anticipating that some random effects related to prevalence variations over time would make it more difficult to interpret potential trends, a second step was taken with the plotting and reevaluation of smoothed prevalence rates using a thirdorder moving average. This step was only adopted for the 2001-2010 period, as this statistical technique is not recommended for analysis of historical data with less than 7 time points. ${ }^{15}$

Next, to address the residue autocorrelation effects determined by time frame proximity, a step-by-step procedure proposed by Antunes and Cardoso ${ }^{15}$ was followed beginning with the ten-base logarithmic transformation of the prevalence rates. Finally, parameter estimations were made by generalized linear regression designated as autoregressive modeling, using the Prais-Winsten method, and with statis- tical significance evaluated via the Durbin Watson test. The annual percent changes (APCs) and their respective 95\% confidence intervals (95\%CIs) were estimated as described by Antunes and Cardoso. ${ }^{15}$ The statistical procedures were performed using The Microsoft Excel Software (Microsoft Corporation, Redmond, WA, US).

\section{Ethical Procedures}

This study followed the recommendations for scientific research involving human subjects, and as it was conducted using de-identified secondary datasets publicly available on the DATASUS website; therefore, it was exempt from formal ethical procedures.

\section{Results}

In Brazil, the number of live births after 22 gestational weeks reached over 30 million during 2001-2010, and over 8 million during 2012-2014. The number of newborns with birth weight $\geq 4,000$ g reached 1,606,330 (2001-2010) and 422,069 (2012-2014), determining an overall prevalence of 5.3\% (2001-2010) and 5.1\% (2012-2014). This indicator decreased slightly $(-8.9 \%)$ when comparing the frequency obtained in 2001 (5.6\%) and in 2010 (5.1\%). There was no change in the 2012-2014 period (-Fig. 1).

Prevalence indicators showed distinct trends according to gestational age strata and time periods. Comparing the preterm strata rates observed in the 2001-2010 period, the prevalence of macrosomia increased both in Brazil as a whole and in four of its five regions, with the Southeast Region registering a variation of zero. The highest increase occurred in the North Region (> 130.0\%). In the 2012-2014 period, macrosomia preterm rates registered a slight negative change. The highest reduction occurred in the South Region (-20.0\%).

In the term strata, from 2001 to 2010 , the prevalence rates for macrosomia decreased in Brazil as a whole and in all regions. In the 2012-2014 period, the frequency was somewhat heterogeneous. The prevalence of newborns born from 37 gestational weeks and weighting $\geq 4,000 \mathrm{~g}$ decreased in Brazil as a whole and in the South Region, but it increased in the North and Southeast Regions. There were no variations in the Northeast and Midwest Regions (-Table 1).

Pictorial representations of the time series allowed the visualization of prevalence trends (solid lines) in Brazil and in every region separately for the 2001-2010 period. Smoothed data (dotted lines) showed that preterm macrosomia prevalence rates changed harmonically during 20042005 (-Fig. 2).

The results indicate statistically significant elevation trends in preterm macrosomic births in the North and South Regions. According to the APCs, the North Region had the most important annual variation (APC: $15.4 \%$; 95\%CI: 0.6-32.3) followed by the South Region (APC: 13.5\%; 95\%CI: 4.8-22.9). In term macrosomic births, the APCs suggest statistically significant declining trends only in the North Region (APC: $-1.5 \%$; $95 \% \mathrm{CI}$ : $-2.5--0.5)$. In Brazil as a whole and in the other four regions, the trends were stationary (-Table $\mathbf{2}$ ). 
Trends in the Prevalence of Live Macrosomic Newbor Nascimento et al. $\mathbf{3 7 9}$

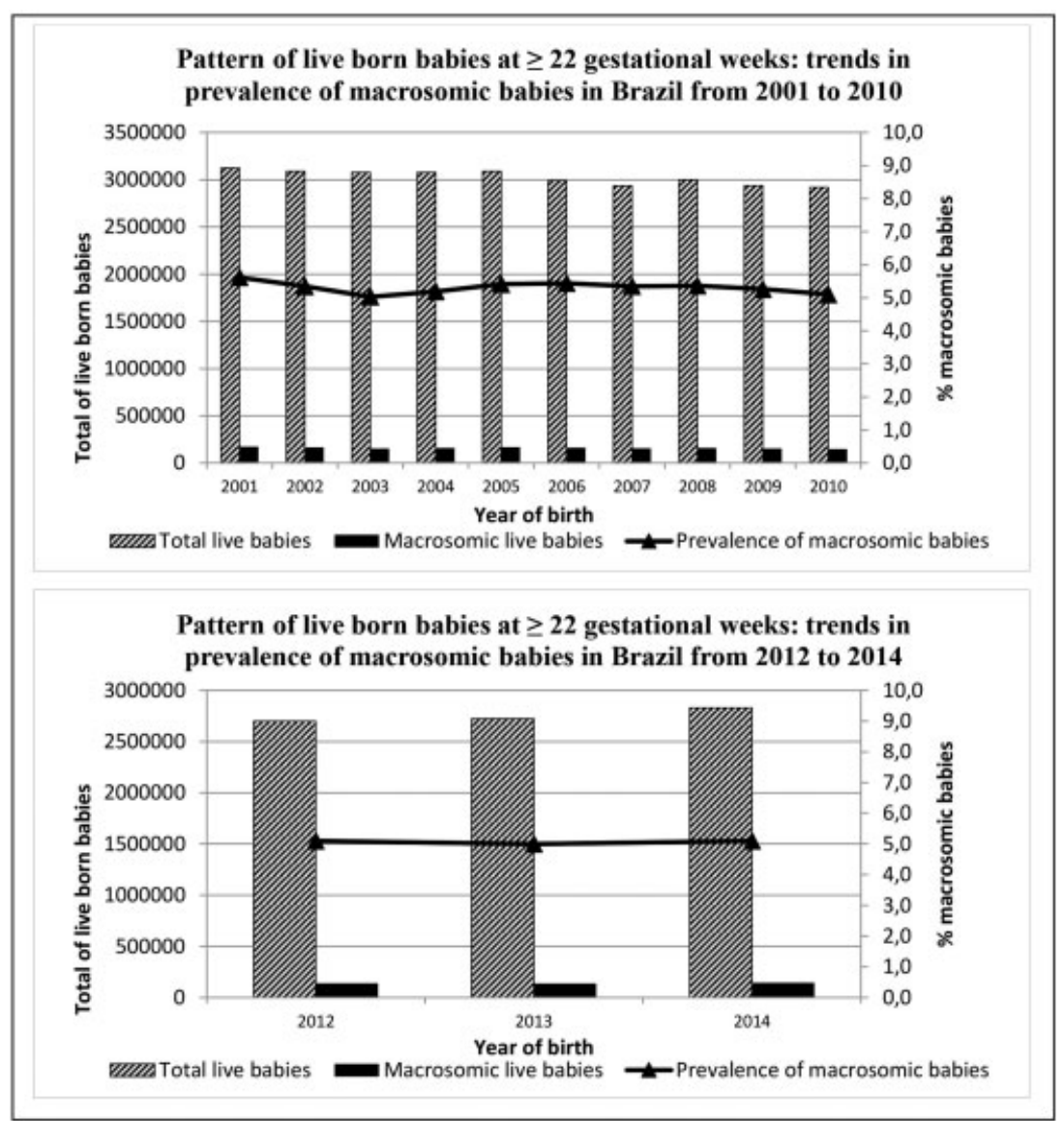

Fig. 1 Birth of live newborns after 22 gestational weeks registered in the Brazillian Live Births Information System (SINASC, in the Portuguese acronym), and trends in the prevalence of macrosomic live newborns in Brazil, from 2001 to 2010, and from 2012 to 2014 . The principal y-axis shows the total number of births. The secondary $y$-axis shows prevalence of macrosomic babies. The $x$-axis shows the year of birth.

Table 1 Prevalence of live macrosomic newborns ( $\geq 4,000 \mathrm{~g}$ ) according to GW strata in Brazil and its regions, from 2001 to 2010 and from 2012 to 2014

\begin{tabular}{|c|c|c|c|c|c|c|c|c|c|c|c|c|}
\hline \multirow[t]{2}{*}{ Year } & \multicolumn{2}{|l|}{ Brazil } & \multicolumn{2}{|l|}{ North } & \multicolumn{2}{|c|}{ Northeast } & \multicolumn{2}{|l|}{ Midwest } & \multicolumn{2}{|l|}{ Southeast } & \multicolumn{2}{|l|}{ South } \\
\hline & $\begin{array}{l}22 \text { to } 36 \\
\text { GW (\%) }\end{array}$ & $\begin{array}{l}37 \text { to } 42 \\
\text { GW (\%) }\end{array}$ & $\begin{array}{l}22 \text { to } 36 \\
\text { GW (\%) }\end{array}$ & $\begin{array}{l}37 \text { to } 42 \\
\text { GW (\%) }\end{array}$ & $\begin{array}{l}22 \text { to } 36 \\
\text { GW (\%) }\end{array}$ & $\begin{array}{l}37 \text { to } 42 \\
\text { GW (\%) }\end{array}$ & $\begin{array}{l}22 \text { to } 36 \\
\text { GW (\%) }\end{array}$ & $\begin{array}{l}37 \text { to } 42 \\
\text { GW (\%) }\end{array}$ & $\begin{array}{l}22 \text { to } 36 \\
\text { GW (\%) }\end{array}$ & $\begin{array}{l}37 \text { to } 42 \\
\text { GW (\%) }\end{array}$ & $\begin{array}{l}22 \text { to } 36 \\
\text { GW (\%) }\end{array}$ & $\begin{array}{l}37 \text { to } 42 \\
\text { GW (\%) }\end{array}$ \\
\hline 2001 & 0.6 & 5.9 & 0.8 & 7.3 & 0.7 & 7.5 & 0.5 & 5.8 & 0.6 & 4.5 & 0.3 & 5.6 \\
\hline 2002 & 0.4 & 5.6 & 0.7 & 6.9 & 0.3 & 7.1 & 0.5 & 5.5 & 0.5 & 4.4 & 0.2 & 5.3 \\
\hline 2003 & 0.3 & 5.3 & 0.6 & 6.4 & 0.4 & 6.5 & 0.2 & 5.2 & 0.4 & 4.2 & 0.2 & 5.0 \\
\hline 2004 & 0.3 & 5.5 & 0.6 & 6.5 & 0.2 & 6.7 & 0.3 & 5.3 & 0.4 & 4.4 & 0.2 & 5.3 \\
\hline 2005 & 0.3 & 5.7 & 0.6 & 6.4 & 0.2 & 7.0 & 0.2 & 5.6 & 0.3 & 4.6 & 0.3 & 5.5 \\
\hline 2006 & 1.0 & 5.7 & 2.5 & 6.5 & 1.5 & 7.1 & 0.8 & 5.6 & 0.7 & 4.6 & 0.5 & 5.3 \\
\hline 2007 & 0.9 & 5.6 & 2.5 & 6.4 & 1.3 & 7.1 & 0.7 & 5.4 & 0.6 & 4.4 & 0.6 & 5.1 \\
\hline 2008 & 0.9 & 5.7 & 1.9 & 6.4 & 1.4 & 6.9 & 0.9 & 5.4 & 0.6 & 4.6 & 0.6 & 5.5 \\
\hline 2009 & 0.9 & 5.5 & 1.8 & 6.3 & 1.4 & 6.8 & 1.0 & 5.3 & 0.5 & 4.5 & 0.5 & 5.3 \\
\hline 2010 & 0.9 & 5.4 & 1.9 & 6.1 & 1.2 & 6.7 & 0.8 & 5.1 & 0.6 & 4.4 & 0.6 & 5.1 \\
\hline $\begin{array}{l}\text { Change* } \\
2001 \\
\text { to } 2010\end{array}$ & 50.0 & -8.5 & 137.5 & -16.4 & 71.4 & -10.7 & 60.0 & -12.1 & 0.0 & -2.2 & 100.0 & -8.9 \\
\hline 2012 & 2.0 & 5.6 & 2.8 & 6.4 & 2.7 & 6.9 & 1.8 & 5.0 & 1.4 & 4.6 & 1.5 & 5.3 \\
\hline 2013 & 1.8 & 5.4 & 2.4 & 6.2 & 2.5 & 6.6 & 1.7 & 5.0 & 1.3 & 4.6 & 1.3 & 5.3 \\
\hline 2014 & 1.8 & 5.5 & 2.5 & 6.5 & 2.6 & 6.9 & 1.5 & 5.0 & 1.2 & 4.7 & 1.2 & 5.2 \\
\hline $\begin{array}{l}\text { Change* } \\
2012 \\
\text { to } 2014\end{array}$ & -10.0 & -1.8 & -10.7 & 1.6 & -3.7 & 0.0 & -16.7 & 0.0 & -14.3 & 2.8 & -20.0 & -1.9 \\
\hline
\end{tabular}

Abbreviation: GW, gestational weeks.

Note: ${ }^{*}$ Change (\%) after comparing the prevalence of macrosomia in 2001 with the prevalence of macrosomia in 2010, and in 2012 with the prevalence in 2014. 


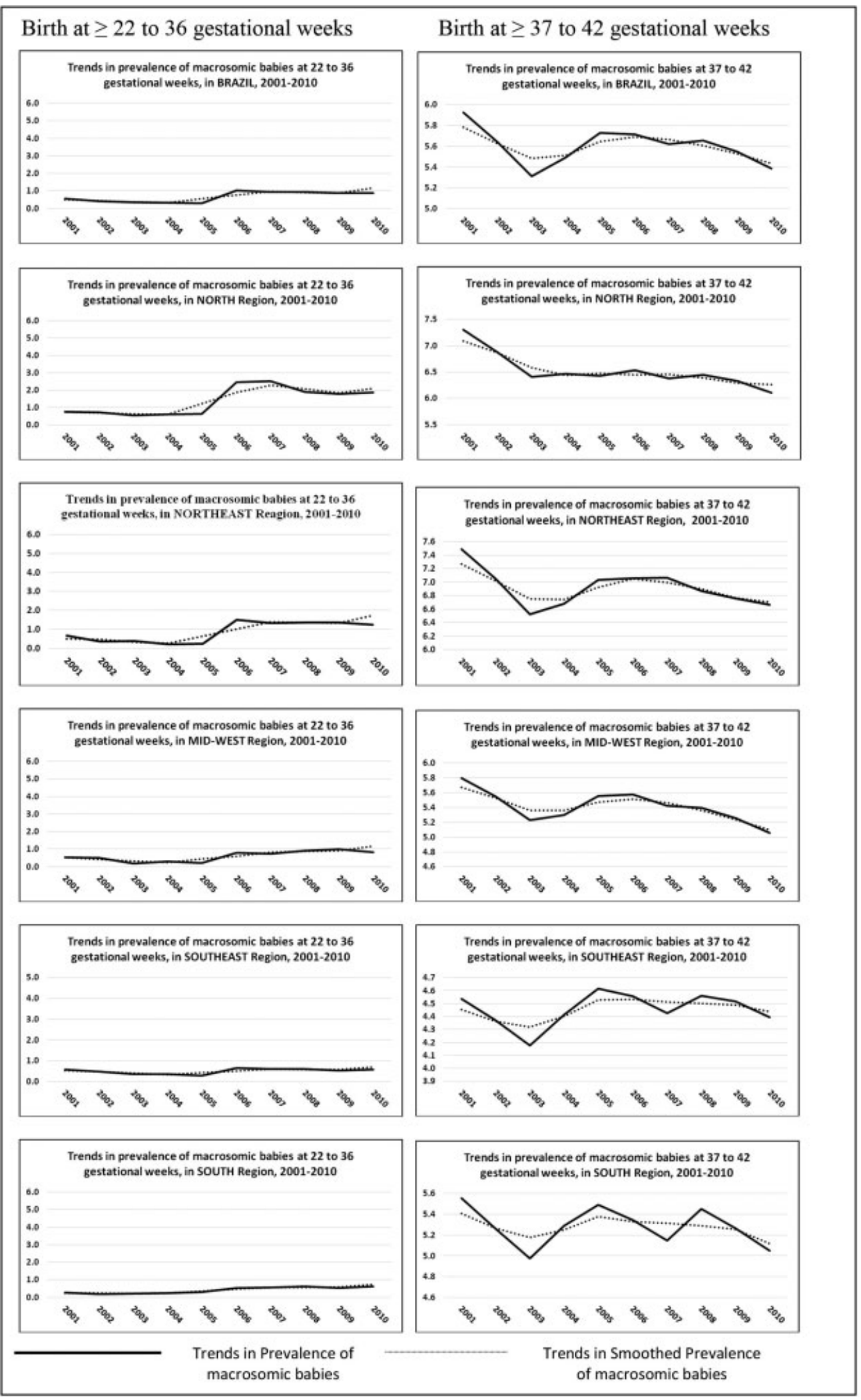

Fig. 2 Trends in prevalence rates and in smoothed prevalence rates of macrosomic live newborns born between 22 to 36 and 37 to 42 gestational weeks, in Brazil and its regions, from 2001 to 2010. The $y$-axis shows the prevalence, and the $x$-axis shows the year of birth. 
Table 2 Trends and APCs in the prevalence of live born macrosomic newborns ( $\geq 4,000 \mathrm{~g})$, Brazil and regions, 2001-2010

\begin{tabular}{|l|l|l|l|l|}
\hline & \multicolumn{3}{|l|}{22 to 36 gestational weeks } & \multicolumn{3}{l|}{37 to 42 gestational weeks } \\
\hline Region & $\begin{array}{l}\text { APCs }(\%) \text { and } \\
95 \% \mathrm{Cl}\end{array}$ & $\begin{array}{l}\text { Trend } \\
\text { Interpretation }\end{array}$ & $\begin{array}{l}\text { APCs }(\%) \text { and } \\
95 \% \mathrm{Cl}\end{array}$ & $\begin{array}{l}\text { Trend } \\
\text { Interpretation }\end{array}$ \\
\hline Brazil & $10.3(-2.1 ; 24.3)$ & stationary & $-0.5(-1.5 ; 0.5)$ & stationary \\
\hline North & $15.4(0.6 ; 32.3)$ & increasing & $-1.5(-2.5 ;-0.5)$ & declining \\
\hline Northeast & $16.8(-2.8 ; 40.6)$ & stationary & $-0.8(-2.0 ; 0.5)$ & stationary \\
\hline Midwest & $12.2(-3.2 ; 30.0)$ & stationary & $-1.1(-2.1 ; 0.0)$ & stationary \\
\hline Southeast & $3.1(-4.5 ; 11.4)$ & stationary & $0.2(-0.7 ; 1.0)$ & stationary \\
\hline South & $13.5(4.8 ; 22.9)$ & increasing & $-0.3(-1.2 ; 0.6)$ & stationary \\
\hline
\end{tabular}

Abbreviations: $95 \% \mathrm{Cl}$, 95\% confidence interval; APCs, annual percent changes.

\section{Discussion}

This study focused on large newborns ( $\geq 4,000 \mathrm{~g}$ ) born from 2001 to 2014 in Brazil, excluding the year 2011. The overall prevalence of macrosomic live births in the country as a whole was of 5.3\% (2001-2010) and 5.1\% (2012-2014). This frequency declined over the first period (2001-2010), and remained relatively stationary in the more recent period (2012-2014). The prevalence of macrosomia in the North and Northeast Regions was systematically higher than in Brazil as a whole and in the other regions, both by gestational age strata and by time period.

Over time, the macrosomia among preterm newborns showed an upward trend in Brazil and in its regions, except in Southeast Region, where this problem kept a stationary trend. On the other hand, downward trends were found in the term strata (2001-2010). The macrosomia problem was more heterogeneous in the 2012-2014 time period.

In Brazil, the general indicator of macrosomia was near the lowest estimates found amongst high-income countries (5.0\% to $20.0 \%$ ), but it was higher than the findings concerning term large newborns reported in a Brazilian research coordinated by the World Health Organization (WHO's Global Survey on Maternal and Perinatal Health) conducted by Koyanagi et $\mathrm{al}^{4}$ with 14,804 newborns (4.1\%), and in another study conducted by Ye et $\mathrm{al}^{3}$ with 13,373 newborns (4.4\%). The survey results were restricted only to live births occurring in 3 maternity hospitals between 2004 and 2005. Even though the maternity hospitals were randomly selected in the WHO study, the outcomes presented in our study may be closer to true population parameters, since they reflect SINASC data of almost all live births registered in Brazil.

Reductions in macrosomia rates in Brazil resemble a trend described in South Korea. ${ }^{16}$ Considering all live births in that country, macrosomia dropped by almost half, going from $6.7 \%$ to $3.5 \%$, in the $1993-2010$ period. The lowest rates were correlated with improvements in pregnancy management, particularly for gestational diabetes, considered to be one of the leading causes of fetal macrosomia.

Fetal growth is more prominent in the last month of pregnancy. ${ }^{17}$ However, it was in the preterm strata before the physiological weight gain acceleration expected in the last 4 gestational weeks that the macrosomia frequency became more noticeable, comparing 2012-2014 to 2001-2010 in the present study. In the 2001-2010 period, the estimates were within the limits of prevalence of preterm newborns weighing between 4,000 $\mathrm{g}$ and 5,000 $\mathrm{g}$ obtained with a correctional equation provided by Silveira et al. ${ }^{14}$ For the 2012-2014 period, the estimates were higher than those found in the first period, and this probably reflects the improvement in the quality of the data from SINASC.

In Denmark, a secular trend study involving all live newborns born from 20 gestational weeks from 1973 to 2003 showed that the increase in mean birth weight was of $5.0 \mathrm{~g}$ per year both for boys and girls. Stratifying by gestational age, the birth weight increased $3.5 \mathrm{~g}$ or $4.0 \mathrm{~g}$ per year among term newborns. However, stronger variations were seen among preterm newborns, a group in which the mean birthweight rose $8.3 \mathrm{~g}$ or $9.0 \mathrm{~g}$ per year. ${ }^{18}$

The increase in the frequency of births of heavier preterm newborns is a complex phenomenon for which there are no easy or obvious explanations. Although three major health conditions (diabetes, maternal obesity and maternal weight gain during the gestational period) may account for disproportionate increases in fetal weight, ${ }^{19,20}$ they may also be controlled via adequate prenatal care. Considering the wide prenatal care coverage provided in Brazil as well as the high proportion of women attending six or more prenatal visits, a question opportunely presented is: Why has the frequency of overweight involving preterm newborns increased in Brazil?

Labor induction and cesarean section indicated specifically to deliver a fetus suspected to be overweight for gestational age or macrosomic could partially explain the preterm births of those newborns who experienced higher weight gain and faster intrauterine growth. ${ }^{21}$ In a way, this could reflect in the decline in weight in the last gestational weeks, as recorded in the United States. In that country, Zhang et $\mathrm{al}^{22}$ reported that term and post-term macrosomia rates dropped from $2.2 \%$ to $1.6 \%$ respectively, from 1992 to 2003 , while the rates of labor induction and cesarean section increased from $14.3 \%$ to $27.0 \%$ and from $21.3 \%$ to $25.0 \%$ in the same period respectively.

Statistically significant findings in the term strata (20012010) were observed only in the North Region, maybe as an effect of the pattern of births of macrosomic newborns before 37 gestational weeks. In Beijing, China, the proportion 
of live newborns weighing $\geq 4,000 \mathrm{~g}$ increased from $6.6 \%$ in 1996 to $9.5 \%$ in 2000 , and declined to $7.0 \%$ in $2010 . .^{23}$ This trend was accompanied by gestational age shortening, and by more premature newborns in 2010 (6.6\%) than in 1996 (4.1\%). According to Shan et $\mathrm{al}^{23}$ the magnitude of the prevalence of macrosomia could be reflecting an excessive maternal gestational weight gain, a situation maximized by both socioeconomic progress and increased consumption of highly caloric foods, which has been typical during these nutritional transition years.

The smoothing statistical method eliminates some effects related to random fluctuations and facilitates the visualization of cyclical or seasonal components in time series studies. ${ }^{15}$ Inflections coincided in the years 2004 and 2005. As descriptive analyses are inappropriate to draw causal inferences, it would be important to conduct further research to verify whether public policies to combat hunger and to improve income distribution, along with its resulting socioeconomic improvement, could partially explain the variations in macrosomia rates found in Brazil.

It is noteworthy that there is evidence showing that the initiative entitled Family Grant Program (Programa Bolsa Família - PBF, in the Portuguese acronym) is associated to an increase in the number of prenatal visits, and to a reduction in low birth weight, particularly in the less-affluent regions, such as the Northeast region of Brazil. ${ }^{24}$ Conditional money transfers via PBF were accelerated in the 2004-2005 biennium, and they expanded rapidly throughout Brazil. The contingent of benefited families grew from 10 million to 12 million between 2008 and 2009, reaching almost 13 million in 2011. The target was the poorest people living in the North and Northeast Regions of the country, but PBF coverage currently reaches all Brazilian municipalities. ${ }^{25}$ The question was raised above because social investment in the country has aimed to achieve the best results in terms of the improvement in quality of life of the poorest people in Brazil. Studies showed that the increase in fetal macrosomia followed a socioeconomic improvement in some regions of China, ${ }^{26}$ outlining a context that might resemble the changes that are happening in Brazil.

Fetal weight influences maternal and perinatal outcomes. The North and Northeast Regions experienced higher macrosomia prevalence, suggesting that regional inequalities may be determining the worst results in those regions compared with Brazil as a whole and to the more affluent Southeast, Midwest and South Regions. In accordance with data from the report Saúde Brasil 2013, ${ }^{27}$ only $57.0 \%$ and $67.0 \%$ of mothers from the North and Northeast Regions had 6 or more prenatal visits, in 2012 respectively. The frequency of mothers who had up to 3 appointments was unacceptably high both in the North (21.0\%) and in the Northeast (14.1\%) Regions. Considering that fetal weight gain is influenced in a way by optimal prenatal care, this highlights the importance of improving the frequency of mothers attending six or more prenatal visits in the North and Northeast Regions.

Public policies focusing on the poorest people have relatively more positive impact on the income of people living in the poorest regions. ${ }^{28}$ For example, the per capita amount received in 2006 by families in the 10 poorest states in the country via the PBF was almost double the amount received by those in the 10 richest states. ${ }^{29}$

Dependence on the PBF benefit is greater in the North and Northeast compared with the Southeast Region. Such circumstance seems to be related to a high consumption in the former of unhealthy foods such as sugar, fat, coffee, beans and soft drinks. ${ }^{30}$ Moreover, an insufficient prenatal coverage reduces the possibility of controlling the conditions related to macrosomia, mainly among minorities living in socioeconomically disadvantaged areas. In view of these problems, the magnitude of the prevalence found in the present study suggests the difficulty of tackling macrosomia conditions in some Brazilian regions.

Some limitations should be mentioned. This study was developed with data from a secondary vital statistics source in which databases were fed with information collected by healthcare workers on a day-to-day basis. However, SINASC is an official live birth records system that covers all of the national territory, and it is the main source of birth data in Brazil. Even though in this study the parameter was prevalence, inconsistent values present in large databases must be dealt with appropriately. However, no studies were found regarding inconsistencies in large-newborn birth weight values in the SINASC database, or that recommended any data correction for the rates found therein.

Another limitation was that macrosomia was based on the cut-off birth weight at $\geq 4,000 \mathrm{~g}$, and this prevented comparisons with studies that used other definitions. Furthermore, changes in the gestational age calculation inserted in the birth certificate form in 2011 hindered the development of the secular analysis for the entire period (2001-2014). The prevalence was instead estimated for separate time periods (2001-2010 and 2012-2014). The performance of statistical procedures was possible only for the first period (20012010 ), since only 3 time points were available in the final period (2012-2014).

Finally, the prevalence of macrosomia was calculated in relation to all live births from 22 gestational weeks, including newborns weighting $\geq 500$ g. Even so, the prevalence was higher than the estimates found in previous studies that only included live births of newborns weighing $\geq 1,000 \mathrm{~g}^{3,4}$

In conclusion, the prevalence of live newborns weighing $\geq 4,000 \mathrm{~g}$ was higher than $5 \%$, and the trends in Brazil were heterogeneous. The upward trend in preterm macrosomic births was a finding that may partially explain the downward trend found among heavy newborns born from 37 gestational weeks in 2001-2010. In the 2012-2014 period, the preterm rates were systematically higher than in the 2001-2010 period, although they were almost stationary among term newborns. Considering the causes and effects of macrosomia in maternal and perinatal morbimortality, as well as their potential implications on the child's and adult's health, fetal macrosomia requires more attention in the Brazilian public healthcare agenda, and more support for investigation and intervention.

Conflicts of Interest

There are no conflicts of interest to declare. 
Financial Support

The study did not receive any financial support.

\section{References}

1 Chatfield J; American College of Obstetricians and Gynecologists. ACOG issues guidelines on fetal macrosomia. Am Fam Physician 2001;64(01):169-170

2 Aye SS, Miller V, Saxena S, Farhan M. Management of large-forgestational-age pregnancy in non-diabetic women. Obstet Gynecol 2010;12(04):250-256

3 Ye J, Torloni MR, Ota E, et al. Searching for the definition of macrosomia through an outcome-based approach in low- and middle-income countries: a secondary analysis of the WHO Global Survey in Africa, Asia and Latin America. BMC Pregnancy Childbirth 2015; $15: 324$

4 Koyanagi A, Zhang J, Dagvadorj A, et al. Macrosomia in 23 developing countries: an analysis of a multicountry, facilitybased, cross-sectional survey. Lancet 2013;381(9865):476-483

$5 \mathrm{Kc} \mathrm{K}$, Shakya S, Zhang H. Gestational diabetes mellitus and macrosomia: a literature review. Ann Nutr Metab 2015;66(Suppl 2):14-20

6 Pía Juárez S. Quality of the Spanish Vital Statistics to estimate perinatal health outcomes: small and large for gestational age. Rev Esp Salud Publica 2015;89(01):85-91

7 Araujo Júnior E, Peixoto AB, Zamarian AC, Elito Júnior J, Tonni G. Macrosomia. Best Pract Res Clin Obstet Gynaecol 2017;38:83-96

8 World Association of Perinatal Medicine. Matres Mundi International. Recommendations and Guidelines for Perinatal Medicine. Barcelona: Matres Mundi; 2007

9 Qiao Y, Ma J, Wang Y, et al; ISCOLE Research Group. Birth weight and childhood obesity: a 12-country study. Int J Obes Suppl 2015; 5(Suppl 2):S74-S79

10 Schellong K, Schulz S, Harder T, Plagemann A. Birth weight and long-term overweight risk: systematic review and a meta-analysis including 643,902 persons from 66 studies and 26 countries globally. PLoS One 2012;7(10):e47776

11 Smith NR, Jensen BW, Zimmermann E, Gamborg M, Sørensen TI, Baker JL. Associations between birth weight and colon and rectal cancer risk in adulthood. Cancer Epidemiol 2016;42:181-185

12 Harder T, Rodekamp E, Schellong K, Dudenhausen JW, Plagemann A. Birth weight and subsequent risk of type 2 diabetes: a metaanalysis. Am J Epidemiol 2007;165(08):849-857

13 Szwarcwald CL, Morais Neto OL, Frias PG, et al. Busca ativa de óbitos e nascimentos no Nordeste e na Amazônia Legal: estimação das coberturas do SIM e do Sinasc nos municípios brasileiros [Internet]. In: Brasil. Ministério da Saúde. Secretaria de Vigilância em Saúde. Departamento de Análise de Situação de Saúde. Saúde Brasil 2010: análise da situação de saúde e de evidências selecionadas de impacto de ações de vigilância em saúde. Brasília (DF): Ministério da Saúde; 2011 [cited 2016 Jan 20]. p. 79-98. Available from: http:// bvsms.saude.gov.br/bvs/publicacoes/saude_brasil_2010.pdf

14 Silveira MF, Matijasevich A, Horta BL, et al. [Prevalence of preterm birth according to birth weight group: a systematic review]. Rev Saude Publica 2013;47(05):992-1003

15 Antunes JLF, Cardoso MRA. [Using time series analysis in epidemiological studies]. Epidemiol Serv Saúde 2015;24(03):565-576 Portuguese
16 Kang BH, Moon JY, Chung SH, et al. Birth statistics of high birth weight infants (macrosomia) in Korea. Korean J Pediatr 2012; 55(08):280-285

17 Filkaszova A, Chabada J, Stencl P, et al. Ultrasound diagnosis of macrosomia. Bratisl Lek Listy (Tlacene Vyd) 2014;115(01):30-33

18 Schack-Nielsen L, Mølgaard C, Sørensen TI, Greisen G, Michaelsen KF. Secular change in size at birth from 1973 to 2003: national data from Denmark. Obesity (Silver Spring) 2006;14(07):1257-1263

19 Viecceli C, Remonti LR, Hirakata VN, et al. Weight gain adequacy and pregnancy outcomes in gestational diabetes: a meta-analysis. Obes Rev 2017;18(05):567-580

20 Walsh JM, McAuliffe FM. Prediction and prevention of the macrosomic fetus. Eur J Obstet Gynecol Reprod Biol 2012;162(02): 125-130

21 Donahue SM, Kleinman KP, Gillman MW, Oken E. Trends in birth weight and gestational length among singleton term births in the United States: 1990-2005. Obstet Gynecol 2010;115(2 Pt 1):357-364

22 Zhang X, Joseph KS, Kramer MS. Decreased term and postterm birthweight in the United States: impact of labor induction. Am J Obstet Gynecol 2010;203(02):124.e1-124.e7

23 Shan X, Chen F, Wang W, et al. Secular trends of low birthweight and macrosomia and related maternal factors in Beijing, China: a longitudinal trend analysis. BMC Pregnancy Childbirth 2014;14:105

24 Santos LMP, Guanais F, Porto DL, et al. Peso ao nascer entre crianças de famílias de baixa renda beneficiárias e não beneficiárias do Programa Bolsa Família da Região Nordeste (Brasil): pareamento CadÚnico e Sinasc [Internet]. In: Brasil. Ministério da Saúde. Secretaria de Vigilância em Saúde. Departamento de Análise de Situação em Saúde. Saúde Brasil 2010: uma análise da situação de saúde e de evidências selecionadas de impacto de ações de vigilância em saúde. Brasília (DF): Ministério da Saúde; 2011 [cited 2016 Abr 7]. p. 271-93. Available from: http://bvsms. saude.gov.br/bvs/publicacoes/saude_brasil_2010.pdf

25 Segura-Pérez S, Grajeda R, Pérez-Escamilla R. Conditional cash transfer programs and the health and nutrition of Latin American children. Rev Panam Salud Publica 2016;40(02):124-137

26 Lu Y, Zhang J, Lu X, Xi W, Li Z. Secular trends of macrosomia in southeast China, 1994-2005. BMC Public Health 2011;11:818

27 Brasil. Ministério da Saúde. Secretaria de Vigilância em Saúde. Departamento de Análise de Situação em Saúde [Internet]. Saúde Brasil 2013: uma análise da situação de saúde e das doenças transmissíveis relacionadas à pobreza. Como nascem os brasileiros. Brasília (DF): Ministério da Saúde; 2014 [cited 2016 Set 7]. Available from: http://portalsaude.saude.gov.br/images/pdf/2015/janeiro/28/ saude-brasil-2013-analise-situacao-saude.pdf

28 Campello T, Neri MC (org). Programa Bolsa família: uma década de inclusão e cidadania: sumário executivo. Brasília (DF): IPEA; 2014 [cited 2017 Maio 11]. Available from: http://repositorio.ipea.gov. br/bitstream/11058/2082/5/Sum\%C3\%A1rio_executivo-LivroPrograma_Bolsa_Fam\%C3\%ADlia-uma_d\%C3\%A9cada_de_inclus\% C3\%A3o_e_cidadania.pdf

29 Silveira-Neto RM, Azzoni CR. Social policy as regional policy: market and nonmarket factors determining regional inequality. J Reg Sci 2012;52(03):433-450

30 de Bem Lignani J, Sichieri R, Burlandy L, Salles-Costa R. Changes in food consumption among the Programa Bolsa Família participant families in Brazil. Public Health Nutr 2011;14(05):785-792 